\title{
The Formulation of Strategies to Export Development in SMEs through SWOT Analysis: A Case Study in Tehran Province
}

\author{
Dr. Abdolmajid Sheykhi ${ }^{1}$, Dr. Abbas Ali Ghayoomi ${ }^{2}$, Abbas Ali Hosseinian Dastjerdi ${ }^{3}$ \\ 1,2,3 Islamic Azad University of Tehran north branch, Business faculty, Tehran, Iran
}

\begin{abstract}
Staggering competition, development of emerging markets, uncertain environmental factors, creation of new technologies, and development of communication and finally business development require well identification of internal and external environments of an enterprise in order to survive in today's competitive world by choosing the right strategy. This study was conducted with the aim of developing export development strategies in small and medium-sized enterprises (SMEs). The study population included all small and medium-sized enterprises in Tehran. According to the statistics of organization of industry, mine and trade of Tehran Province, there are 89 small and medium-sized enterprises and considering this small number, the entire population was selected as sample. This study is an applied research in terms of purpose and field method was used for data collection. The questionnaire used in this study is adapted from strategic management expert; Fred R. David and it is a standard questionnaire. SWOT matrix is used to develop the strategy. The results of this study show that the main environmental opportunities include: existence of commercial networks and databases, support of enterprises for creation of strong business organizations and the possibility of development and acquisition of more market share. Also incomplete banking relationships, traditional methods for transaction, presence of strong industrial-commercial competitors and the entry of Chinese goods to the target markets are considered the main threats. The major strengths included: benefiting from export credits and incentives, using effective procedures and policies to control inventories and using quality and cost management technique. Finally, the most significant weaknesses in these enterprises include: inadequate working capital, lack of effective marketing and budgeting programs and lack of impressive demand for exportable goods. Strategies such as creating market research centers, designing new product, trying to find new markets and strengthening production technology are some of the most important findings of this research.
\end{abstract}

Keywords: business development, export development strategies, strategic planning, small and medium-sized enterprises, SWOT matrix, Tehran province

\section{Introduction}

Export as the driving engine of economy and the key factor for survival of country in the global markets, plays an important role in economy; because strengthening production capacities and creating new capacities, while smooth the path for export development, can increase the role of government as the guarantor of existing investments and monopoly reduction, as well. On the other hand, the export provides the possibility of using global markets for GDP growth and extricates manufacturing enterprises from limitations of domestic market and enables them to target global markets and further utilize the economic benefits of production through export development. One of the most important tools to develop export is designing a strategy to penetrate in foreign markets and to increase market share.

Today, small and medium-sized enterprises (SMEs) are regarded as the most important factor in development of industrial structure in many countries. Such industries are very crucial for many developing countries which are seeking to restore their economic structure and they should focus on development of small and medium industries in order to accelerate the industrialization process. These enterprises often rely on internal resources and they strengthen the growing trend of employment. SMEs are very important in the economy of different countries.

In today's world, complex developments are occurring rapidly and it has become a challenge for many countries to deal with these developments. These challenges stem from the fact that rapid and complex developments are creating a new society where in addition to the formation of a new type of international division of labor, social and political issues will be affected in different countries. Also, trade and investment are known as powerful development tools and different countries have focused on these tools. Trade and investment can lead to opening new markets and providing access to them, expanding production capacity and increasing the level of income and employment.[1]

Competitiveness is a fundamental issue and there are different criteria for its assessment. Competitiveness can help policymakers to assess situation of foreign trade in a country. In the current economic situation of the world in which one of the major concerns of our country is joining the World Trade Organization, competitiveness means access to an appropriate position and stability in the global markets. Creating and supporting small and medium-sized enterprises is one of the main priorities in economic development programs in many developed and developing countries. SMEs play an important role in job creation and creating suitable grounds for innovation and increasing exports.[2]

SMEs are the backbone of economy and they have created more than $50 \%$ of employment and $80 \%$ of employment growth in the past decade; therefore it is necessary to assess the value of approaches such as strategic management to improve the performance of these companies. [3] 


\section{International Journal of Science and Research (IJSR) \\ ISSN (Online): 2319-7064}

Index Copernicus Value (2013): 6.14 | Impact Factor (2015): 6.391

Development of a strategy, consistent with export development is an undeniable necessity. One of the most important tools in export development strategy is taking advantage of competitive advantage in foreign exchanges sphere and realization of this issue will not be possible without a strategic plan.[4] This issue and lack of clear strategy for export development in small and medium-sized enterprises are the main issues addressed by this study. In this study, in addition to explaining the role of SMEs in the area of foreign trade in a province and analyzing industry and identifying their strengths, weaknesses and also their problems in the export arena, strategies will be specified for development of competitive environment and for export development, based on analysis of competitive environment and SWOT matrix.

\section{Research background}

\subsection{Domestic researches}

1.Dr. Mehrdad Madhoushi and Ghaffar Tari in their study entitled "export development strategies in Mazandaran province" after identification of advantageous items and target markets, through using SWOT technique and David models they concluded that strategies including: market development, concentric diversification, product development and market penetration are appropriate and the major strategies. Also, the overall strategies which they presented included:

- Utilization of information technology and e-commerce

- Equipment of transportation fleet and customs organization to develop export

- Improvement of road transportation

- Improvement of marine transportation[5]

2. Dr Davoud Feiz within the strategic document of development of foreign trade in Semnan province, by using SWOT technique and David models, in addition to extraction of the list of key relevant strengths (S1 to S9), key relevant weaknesses (W1 to W11), key opportunities (O1 to O11) and key threats (T1 to T12) presented the key strategies to improve qualitative and quantitative indicators of business services development, promotion of quantitative and qualitative indicators of export development and increasing competitiveness of active economic enterprises at the national and international levels.

Some of these key strategies related to the major objectives of foreign trade development include:

- Development and promotion of knowledge and skills of traders, businessmen, manufacturers and authorities in foreign trade in the province

- Facilitating the communication of manufacturing enterprises and businessmen with target markets

- Planning with the aim of reducing the cost of production and exportable services

- Generation and distribution of required information for manufacturing and services enterprises, in order to enter the international markets[6]

3. Dr. Reza Shafei within the strategic document of development of foreign trade in Kurdistan province enumerates key strategies related to the realization of the major objectives of foreign trade development -obtained by using SWOT technique and David models- as following:

- Promotion of export knowledge and culture, at the provincial level

- Providing Specialized trainings and informing exporters and those involved in foreign trade

- Conducting studies and researches on target export markets

- Development and strengthening infrastructures and providing appropriate services to export goods and services

- Determining priorities and export competitive advantages in the province

- Development of political and economic relations with neighboring provinces in Iraq

- Developing and strengthening export unions in the province

- Maintaining and developing exports to Iraq

- -Development and focusing on exporting high-quality products and services[7]

4. Mohammad Mehdi Bahram Zadeh in a study entitled "investigating the role of strategic management on competitiveness of SMEs" specified the advantages of using strategic management in SMEs and analyzed its effect in increasing the competitiveness of these enterprises in their path toward export development. Some of these strategic advantages include:

- Marketing and distribution factors

- Production Management

- Human resources and capital

- Research and development

- Changing authorities' attitude, regarding determination of policies for SMEs

- Establishment and strengthening systematic thinking and identification of strategic factors in the development of competitive strategies[8]

5. Amir Atarodian in a study entitled "enhancing export competitiveness of SMEs" investigated the situation of export competitiveness of SMEs in developing countries and analyzed the mechanisms to enhance export competitiveness. He eventually concluded that the best approach for SMEs in order to access foreign markets is through export. These enterprises can access foreign markets through export in three ways:

- Independent SMEs which are specialized in a specific area and produce very profitable products.

- SMEs which are connected with transnational corporations or large domestic export companies.

- SMEs which are components of categories, groups or networks and focus on strengthening competition at international levels.[9]

6. Mansour Asgari, in a research entitled "how to make the SMEs competitive in order to develop exports?" after analyzing situation of SMEs and trade policies in Iran and other countries, enumerated the key research findings in this regard as: reforming management, reforming and optimization of production methods to increase productivity, controlling production costs and prices of exportable goods. 


\section{International Journal of Science and Research (IJSR) \\ ISSN (Online): 2319-7064}

Index Copernicus Value (2013): 6.14 | Impact Factor (2015): 6.391

Also, dimensions of governments' supports for small and medium industries include:

- Loans and Credits

- Technology

- Consulting Services

- Intelligence support

- Scientific capacity building

- Offering credits and facilities to establish enterprises[10]

\subsection{International researches}

United Nations Industrial Development Organization (UNIDO) in a research entitled "a strategy to increase effective and competitive participation of small and medium-sized industries in Iran's economic and industrial development" translated by Abdolreza Shaghaghi and Masoud Shafiee, in addition to explaining the role of small and medium-sized industries in the international trade, enumerates the most important policy recommendations to develop export which include: business cooperation programs, subcontracting programs, exchanging cooperation and investment promotion program with the aim of national and local investments for small and medium-sized enterprises (the study population included small and medium-sized industries in Iran). [11]

2.Martin and Correa, in a study entitled "environment and export strategy in SMEs" indicated major domestic and foreign obstacles of SMEs regarding the issue of export as follows:

Domestic obstacles: lack of information, lack of capital or credit, inadequate management skills.

Foreign obstacles: technical-commercial limitations, marketing problems, lack of risk insurance and transportation costs.

3. Spenser (1988), in a theory states that founders of strategic business policy in early 1980 believed that formulating business strategy is possible in two phases:

A) Selecting industries, B) Targeting selected industries through commercial and industrial strategic policy tools.[12]

\section{Methodology}

The main aim of this research was to identify export development strategies in SMEs in Tehran province.

If according to the research literature we cannot predict a special direction to describe relationships or differences between research variables, then we must raise research questions.[13]

In other words, in those researches which we try to understand the nature of a phenomenon or when we ask people about their opinions regarding a phenomenon, we must raise a question and in cases where we want to study the causal relationship or correlation between two or more distinct phenomena, we utilize research hypothesis.

So, considering the nature of this study which is providing strategy, we raise questions -instead of hypotheses- in this section and these questions include:

\subsection{The main question}

Which strategies are appropriate for export development in small and medium-sized enterprises in Tehran?

\subsection{The secondary question}

1) What are the economic opportunities for export development in small and medium-sized enterprises?

2) What are the economic threats for export development in small and medium-sized enterprises?

3) What are the strengths of small and medium-sized enterprises?

4) What are the weaknesses of small and medium-sized enterprises?

The conceptual model of this research has been adapted from Fred R. David (see Appendix A).

In this study, we have only conducted the first phase of this model that is strategy formulation. [14]

The study population includes 87 managers of small exporting enterprises in Tehran. Given the small number of statistical population, we considered the entire population as the sample. So, the sample includes the entire statistical population.

In the field studies, questionnaire was used as a tool to collect data. In better words, opinions of experts and managers of small and medium-sized enterprises were used to collect data, through a questionnaire within the framework of a model to analyze internal strengths and weaknesses and external opportunities and threats (SWOT) to develop exports in small and medium-sized enterprises in Tehran province. This questionnaire consisted of 37 questions. 87 questionnaires were delivered to the target population and 82 questionnaires were collected.

\section{Results}

In order to analyze collected data, the descriptive statistics which studies demographic variables, including gender, age, education, type of enterprise, activity record, amount of exports and etc. - was applied. Then in the inferential statistics, we used success ratio test to determine strengths, weaknesses, opportunities and threats to form the SWOT matrix and finally we utilized Friedman test to rank each of the components of SWOT matrix.

Four types of questions were tested in order to answer research questions to determine the level of agreement or disagreement of respondents with the items raised as opportunities, threats, strengths and weaknesses. So, there are two hypotheses in this test:

Hypothesis $\mathrm{H} 0$ states that with the probability of $60 \%$ or less, the respondents won't consider raised items as opportunities, threats, strengths and weaknesses and hypothesis $\mathrm{H} 1$ states that with the probability of more than $60 \%$, the respondents will consider raised items as opportunities, threats, strengths and weaknesses.

$\mathrm{H} 0: \mathrm{p} \leq 0.60$ 


\section{International Journal of Science and Research (IJSR) \\ ISSN (Online): 2319-7064 \\ Index Copernicus Value (2013): 6.14 | Impact Factor (2015): 6.391}

$\mathrm{H} 1: \mathrm{p}>0.60$

The results of this test at the confidence interval of $95 \%$ indicate that the test statistic related to questions number 1 to36was very close to zero and since ( $\mathrm{Sig}=0,000<\alpha=0,05$ ) so the null hypothesis (H0) is rejected for all items and the alternative hypothesis (H1) is accepted. Therefore, we can say that more than $60 \%$ of raised items are considered as opportunities, threats, strengths and weaknesses of small and medium-sized enterprises by respondents. But regarding question number 37 , because ( $\operatorname{Sig}=0,304>\alpha=0.05)$, so the null hypothesis (H0) is not rejected and we can't say that this is considered as one of the weaknesses of small and medium-sized enterprises.

After obtaining different dimensions of SWOT strategy, they were prioritized by using Friedman test and results are presented in figure1.

This test is used to examine the similarity of prioritization of a number of variables.

H0: SWOT factors have similar priorities.

$\mathrm{H} 1$ : At least one factor has a different priority, comparing to the others.

\begin{tabular}{|c|c|}
\hline \multicolumn{2}{|c|}{ Figure 1: The output and results of Friedman test } \\
\hline$N$ & 82 \\
\hline Chi-Square & 667.729 \\
\hline$d f$ & 36 \\
\hline Asymp. Sig. & .000 \\
\hline
\end{tabular}

Figure2. Chi-square distribution

\begin{tabular}{|c|c|c|}
\hline \multirow{2}{*}{$d f$} & \multicolumn{2}{|c|}{ Asymp. Sig. } \\
\cline { 2 - 3 } & 0.05 & 0.01 \\
\hline 29 & 42.56 & 49.59 \\
\hline 30 & 43.77 & 50.89 \\
\hline 40 & 55.76 & 63.69 \\
\hline 50 & 67.50 & 76.15 \\
\hline
\end{tabular}

As the figure 2 indicates, we can observe the value of Chisquare statistic with 36 degrees of freedom and zero significance level which indicates that the $\mathrm{H} 0$ is rejected. According to the above outputs, the final result is that at least one of the factors has a different priority. Research indicators and dimensions are ranked by using questionnaire data and through utilizing Friedman test.(see Appendix B)

\subsection{SWOT analysis and formulating export development strategies}

As mentioned before, the aim of this research is to develop strategic solutions and to determine appropriate strategy or strategies in order to develop export in small and mediumsized enterprises which will lead to an increase in export share of a province in national export basket. We utilized SWOT analysis method in order to achieve this objective and to determine appropriate strategies. Therefore, at the first step in order to determine the final list of priority of strengths and weaknesses and to determine opportunities and threats, we analyzed internal and external factors affecting export development.
4.1.1 Analysis of external environment (external factors) The aim of studying external factors is to prepare a list of opportunities which can be utilized or threats which can be avoided. An opportunity is an external state which can positively affect performance parameters within an organization or enterprise and can improve the competitive advantage of positive actions at the appropriate time. Matrix of external factors can evaluate economic, social, cultural, ecological, environmental, political, governmental, legal, technological and competitive factors.[15]

Thus, we can classify the most important opportunities regarding export in small and medium-sized enterprises in Tehran province, approved by research experts as following:

1) Existence of commercial networks and databases

2) Support of enterprises for creation of strong business organizations

3) The possibility of development and acquisition of more market share

4) Growth of production culture and promotion of export culture

5) The possibility of establishment of large holding industries and creation of homogeneous industrial clusters

6) High market capacity for export

7) Existence of special advantages to attract demands, by considering customers' needs and preferences

Also, a threat is an external state which can negatively affect performance parameters within an organization or enterprise and can decrease the competitive advantage of positive actions at the appropriate time. So, major threats which can threaten export in small and medium-sized enterprises in Tehran province include:

1) Incomplete banking relationships and traditional methods for transaction

2) Presence of strong industrial-commercial competitors

3) The entry of Chinese goods to the target markets

4) Inadequacy of export supporting infrastructures

5) 5- Exporting poor-quality and inappropriate goods to the target markets

6) Remoteness from the target export market

7) Reluctance of investors to invest in infrastructures

8) Economic instability and fluctuations in inflation and interest rates

9) Sudden changes in commercial laws and standards and imposing excessive costs on traders

10) Absence of an effective international transportation system

11) Lack of professional traders and exporters and specialization of trade

12) The phenomenon of smuggling in our country

\subsubsection{Analysis of internal environment (internal factors)}

Internal environment will be analyzed in order to assess competitive advantage and to explain the strengths and weaknesses of an enterprise or an organization. Internal factors are factors which are usually controlled by managers and administrators. The most important internal factors include management, marketing, finance and accounting, production and operations, research and development and computerized information systems. The strength of an organization or an enterprise is defined as successful 


\section{International Journal of Science and Research (IJSR) \\ ISSN (Online): 2319-7064}

Index Copernicus Value (2013): 6.14 | Impact Factor (2015): 6.391

implementation of a competency or utilization of a key factor in order to develop competitiveness of the enterprise.

The most important strengths regarding export in small and medium-sized enterprises in Tehran province include:

1) Benefiting from export credits and incentives

2) Using effective procedures and policies to control inventories

3) Using quality and cost management technique

4) Appropriate and effective pricing

5) Observing standards and increasing export of highquality goods

6) Conducting marketing activities, marketing advertising and research

7) Familiarity with concepts and principles of strategic management

8) Considering customers' orders and their satisfaction

9) Creating good relations with investors and shareholders

The weakness of an organization or an enterprise is defined as unsuccessful implementation of a competency or nonutilization of a key factor which reduces competitiveness of the enterprise. So, the most important weaknesses regarding export in small and medium-sized enterprises in Tehran province include:

1) Inadequate working capital

2) Lack of effective marketing and budgeting programs

3) Lack of impressive demand for exportable goods

4) Difficult access to advanced technology

5) Absence of specialist and experienced experts in the decision-making body

6) High costs of improving export capacity, through production, promotion and advertisement

7) Lack of modern packing and sorting systems

8) Low investment in research and development

\subsection{Preparation of SWOT evaluation matrix}

After evaluation of internal and external factors which is called the entry phase; information needed to formulate strategies will be determined. In the second phase which is the comparison phase, different kinds of possible strategies will be studied after preparing the SWOT matrix. The purpose of this matrix is to determine applicable strategies and in this study we are not trying to find the best strategy. In SWOT matrix a harmonic and balanced relation is established between the major internal and external factors in the enterprise. Strategists can provide four types of strategies by using this matrix. This matrix is presented in Appendix C.

\section{Conclusion}

In terms of descriptive statistics, data obtained from questionnaires show that more than 80 percent of study population include male and more than half of them are over 45 years old. About 37 percent of them have a bachelor's degree and more than one-third have graduated in humanities disciplines. 60 percent of the studied enterprises were services enterprises and the rest were manufacturing enterprises and the history of activity of more than half of them was over 15 years. 69 percent of these enterprises were members of export unions and 72 percent of them had over 100 thousand dollars of exports during the last 5 years.

Considering issues such as information obtained from data collection and results, descriptive status of components of SWOT strategy and considering agreement of respondents with the items raised as strengths, weaknesses, opportunities and threats and conducting binomial test, it was determined that more than 60 percent of the items raised as strengths, weaknesses, opportunities and threats in the competitive environment and in the area of exports are prioritized -are considered as the most important items- for small and medium-sized enterprises.

So, existence of commercial networks and databases, support of enterprises for creation of strong business organizations and the possibility of development and acquisition of more market share are among the most important opportunities in small and medium-sized enterprises in Tehran.

Also incomplete banking relationships, traditional methods for transaction, presence of strong industrial-commercial competitors and the entry of Chinese goods to the target markets are considered as the main threats.

Benefiting from export credits and incentives, using effective procedures and policies to control inventories and using quality and cost management technique are considered as the main weaknesses.

Finally, inadequate working capital, lack of effective marketing and budgeting programs and lack of impressive demand for exportable goods are considered as the most significant weaknesses in these enterprises.

In order to determine the appropriate strategy or strategies to develop export in SMEs of Tehran in the competitive environment -that was the ultimate goal of this study- after collecting data and descriptive analysis of internal and external environment of SMEs, we developed export development strategies by using SWOT matrix. The most important strategies which are considered as the findings of this study include:

1) Conducting researches to determine customers' needs, Demands and their level of satisfaction

2) Creating market research centers

3) Increasing export infrastructures in enterprises

4) Trying to find new markets and increasing market share

5) Improving the quality of products and packaging systems

6) Improving production technology

7) Development of human resources productivity

8) Strategic alliance of industries and resource sharing

9) Designing new product

\section{Suggestions}

Given the above mentioned facts and considering major internal and external problems of export development, we present following suggestions in addition to the research findings: Human resource development, consulting services, product development, increasing the level of technologies, 


\section{International Journal of Science and Research (IJSR) \\ ISSN (Online): 2319-7064}

Index Copernicus Value (2013): 6.14 | Impact Factor (2015): 6.391

marketing and promotion and strengthening physical infrastructures.

\section{Reference}

[1] Antti.H ,Vivekananda,M ,Ugur.Y ,Emin.B. (2005). '” Cooperative strategy, knowledge intensity and export performance of small and medium sized enterprises" journal of world business 40,124-138.

[2] Bahramzadeh.M. (2010). " Investigation strategic management role in the competitiveness of small and medium-Country",

[3] Analoei.F ,Karami.A. (2012). "' Strategic management in small and medium industries, Amir Kabir, 2th.

[4] Olejnik, E., \& Swoboda, B. (2012). SMEs' internationalisation patterns: Descriptives, dynamics and determinants. International Marketing Review, 29(5), 466-495.

[5] Madhoushi.M , Tari. GH,(2006), "export development strategies in Mazandaran province" Journal of Commerce.

[6] Dr. Feiz.D , (2005), the strategic document of development of foreign trade in Semnan province, Commercial organization of Semnan

[7] Dr. Shafei.R , (2008), The strategic document of development of foreign trade in Kurdistan province, The research system of Kurdistan university.
[8] Bahram Zadeh.M.M ,(2009), "investigating the role of strategic management on competitiveness of SMEs", The third international conference of strategic management, Tehran, NAB group.

[9] Atarodian. A, (2014), "enhancing export competitiveness of SMEs" , Scientific-extension journal, N27, pp 105-110.

[10] Asgari. M, Vali Beygi.H, (2008), "how to make the SMEs competitive in order to develop exports?", Scientific-extension journal, N30, pp103.

[11] Shaghaghi. A, Shafiee. M, (2008), "Strategy document to enhance the contribution of an efficient and competitive small and medium - sized enterprise sector to industrial and economic development in the Islamic republic of iran", United nations industrial development organization.

[12] Spence. B, (1988), "What should trade policy target", Strategic trade policy and new international economics, MIT press, pp.69-88.

[13] Blum, B. S., Claro, S., \& Horstmann, I. J. (2013). Occasional and perennial exporters. Journal of International Economics, 90(1), 65-74.

[14]Fred R.David. (2011). Strategic Management: A Competitive Advantage Approach, Concepts \& Cases. 13 th

[15]Bhagaban Das and Nikhil Chandra Shil and Alok Kumar Pramanik. (2008). "'Strengthening SMEs to make export Competitive'’MPRA Paper No. 7800.

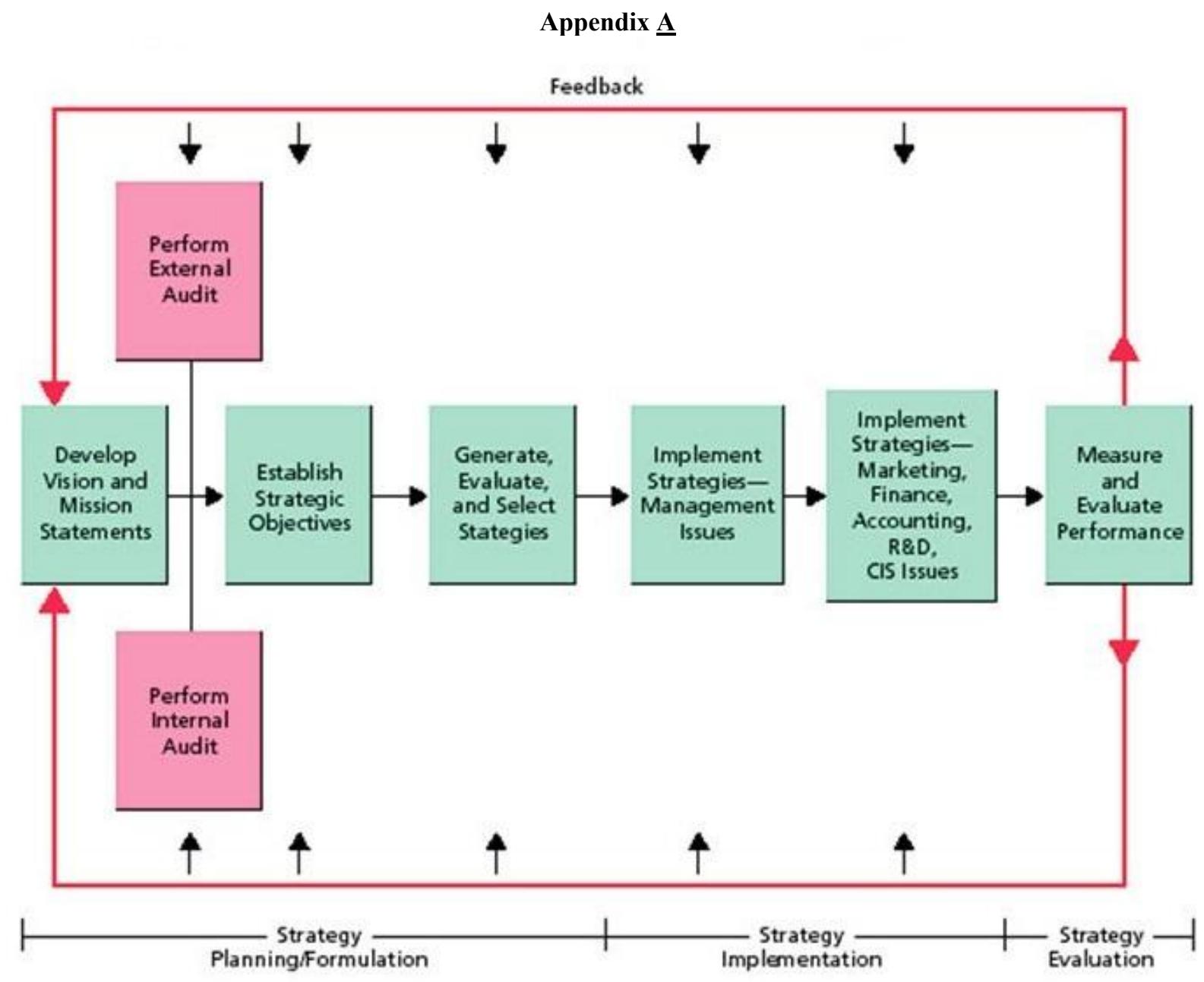

Volume 5 Issue 7, July 2016 www.ijsr.net 


\section{International Journal of Science and Research (IJSR) \\ ISSN (Online): 2319-7064}

Index Copernicus Value (2013): 6.14 | Impact Factor (2015): 6.391

\begin{tabular}{|c|c|c|c|c|c|}
\hline & & & & & \\
\hline \multirow{8}{*}{ Opportunity } & \multirow{8}{*}{2.14} & \multirow{8}{*}{4} & The possibility of establishment of large holding industries and creation of & & \\
\hline & & & homogeneous industrial clusters & 14.95 & 5 \\
\hline & & & Support of enterprises for creation of strong business organizations & 26.87 & 2 \\
\hline & & & Growth of production culture and promotion of export culture & 17.81 & 4 \\
\hline & & & High market capacity for export & 12.52 & 6 \\
\hline & & & $\begin{array}{c}\text { Existence of special advantages to attract demands, by considering customers' } \\
\text { needs and preferences }\end{array}$ & 9.32 & 7 \\
\hline & & & The possibility of development and acquisition of more market share & 18.26 & 3 \\
\hline & & & Existence of commercial networks and databases & 27.87 & 1 \\
\hline \multirow{12}{*}{ Threat } & \multirow{12}{*}{3.00} & \multirow{12}{*}{1} & Remoteness from the target export market & 18.39 & 6 \\
\hline & & & Presence of strong industrial-commercial competitors & 27.70 & 2 \\
\hline & & & The entry of Chinese goods to the target markets & 22.03 & 3 \\
\hline & & & Reluctance of investors to invest in infrastructures & 18.10 & 7 \\
\hline & & & The phenomenon of smuggling in our country & 12.12 & 12 \\
\hline & & & Lack of professional traders and exporters and specialization of trade & 14.11 & 11 \\
\hline & & & Inadequacy of export supporting infrastructures & 21.45 & 4 \\
\hline & & & Economic instability and fluctuations in inflation and interest rates & 17.77 & 8 \\
\hline & & & $\begin{array}{l}\text { Sudden changes in commercial laws and standards and imposing excessive } \\
\text { costs on traders }\end{array}$ & 16.63 & 9 \\
\hline & & & Absence of an effective international transportation system & 16.10 & 10 \\
\hline & & & Incomplete banking relationships and traditional methods for transaction & 27.79 & 1 \\
\hline & & & Exporting poor-quality and inappropriate goods to the target markets & 18.40 & 5 \\
\hline \multirow{9}{*}{ Strength } & \multirow{9}{*}{2.43} & \multirow{9}{*}{3} & Familiarity with concepts and principles of strategic management & 16.41 & 7 \\
\hline & & & Using quality and cost management technique & 22.88 & 3 \\
\hline & & & Appropriate and effective pricing & 20.55 & 4 \\
\hline & & & Considering customers' orders and their satisfaction & 15.02 & 8 \\
\hline & & & Benefiting from export credits and incentives & 28.48 & 1 \\
\hline & & & Conducting marketing activities, marketing advertising and research & 16.50 & 6 \\
\hline & & & Creating good relations with investors and shareholders & 14.55 & 9 \\
\hline & & & Using effective procedures and policies to control inventories & 25.55 & 2 \\
\hline & & & Observing standards and increasing export of high-quality goods & 18.64 & 5 \\
\hline \multirow{8}{*}{ Weakness } & \multirow{8}{*}{2.45} & \multirow{8}{*}{2} & Low investment in research and development & 14.08 & 8 \\
\hline & & & $\begin{array}{l}\text { High costs of improving export capacity, through production, promotion and } \\
\text { advertisement }\end{array}$ & 15.12 & 6 \\
\hline & & & Difficult access to advanced technology & 19.16 & 4 \\
\hline & & & Lack of impressive demand for exportable goods & 23.29 & 3 \\
\hline & & & Lack of modern packing and sorting systems & 14.36 & 7 \\
\hline & & & Lack of effective marketing and budgeting programs & 25.90 & 2 \\
\hline & & & Absence of specialist and experienced experts in the decision-making body & 18.21 & 5 \\
\hline & & & Inadequate working capital & 32.13 & 1 \\
\hline
\end{tabular}

Volume 5 Issue 7, July 2016 www.ijsr.net

Licensed Under Creative Commons Attribution CC BY 
International Journal of Science and Research (IJSR)

ISSN (Online): 2319-7064

Index Copernicus Value (2013): 6.14 | Impact Factor (2015): 6.391

\begin{tabular}{|c|c|c|c|}
\hline \multicolumn{4}{|c|}{ Appendix $\underline{C}$} \\
\hline & & $W$ & $S$ \\
\hline & & $\begin{array}{l}W 1 \\
W 2 \\
W 3 \\
W 4 \\
W 5 \\
W 6 \\
W 7 \\
W 8\end{array}$ & $\begin{array}{l}S 1 \\
S 2 \\
S 3 \\
S 4 \\
S 5 \\
S 6 \\
S 7 \\
S 8 \\
S 9\end{array}$ \\
\hline$O$ & $\begin{array}{l}O 1 \\
O 2 \\
O 3 \\
O 4 \\
O 5 \\
O 6 \\
O 7\end{array}$ & $\begin{array}{l}\text { 1- Conducting researches } \\
\text { to determine customers' } \\
\text { needs, Demands and their } \\
\text { level of satisfaction } \\
\text { 2- Creating market } \\
\text { research centers }\end{array}$ & $\begin{array}{l}\text { 1- Increasing export infrastructures } \\
\text { in enterprises } \\
\text { 2- Trying to find new markets and } \\
\text { increasing market share } \\
\text { 3- Improving the quality of products } \\
\text { and packaging systems }\end{array}$ \\
\hline$T$ & $\begin{array}{c}T 1 \\
T 2 \\
T 3 \\
T 4 \\
T 5 \\
T 6 \\
T 7 \\
T 8 \\
T 9 \\
T 10 \\
T 11 \\
T 12\end{array}$ & $\begin{array}{l}\text { 1- Improving production } \\
\text { technology } \\
\text { 2- Development of human } \\
\text { resources productivity }\end{array}$ & $\begin{array}{l}\text { 1- Strategic alliance of industries } \\
\text { and resource sharing } \\
\text { 2- Designing new product }\end{array}$ \\
\hline
\end{tabular}

Volume 5 Issue 7, July 2016

www.ijsr.net

Licensed Under Creative Commons Attribution CC BY 